\title{
Recent evolution of Marmolada glacier (Dolomites, Italy) by means of ground and airborne GPR surveys
}

\author{
I. Santin ${ }^{\text {a }}$, R.R. Colucci ${ }^{\mathrm{b}, *}$, M. Žebre ${ }^{\mathrm{c}}$, M. Pavan ${ }^{\mathrm{d}}$, A. Cagnati ${ }^{\mathrm{e}}$, E. Forte ${ }^{\mathrm{a}}$ \\ a Department of Mathematics and Geosciences, University of Trieste, Italy \\ ${ }^{\mathrm{b}}$ Department of Earth System Sciences and Environmental Technology, CNR - ISMAR, Basovizza, Italy \\ c Department of Geography \& Earth Sciences, Aberystwyth University, United Kingdom \\ ${ }^{\mathrm{d}}$ Department of Earth, Environmental and Life Sciences, University of Genova, Italy \\ e ARPAV - Agenzia Regionale per la Prevenzione e Protezione Ambientale del Veneto, Arabba, BL, Italy
}

\section{A B S T R A C T}

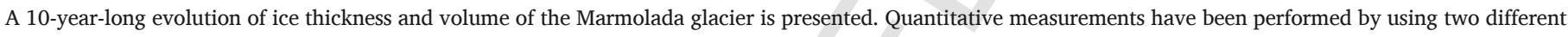

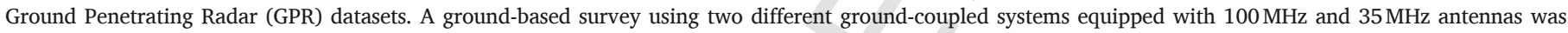

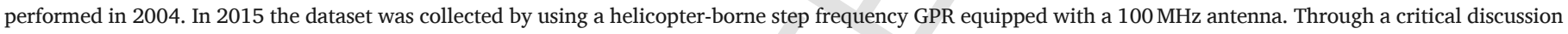

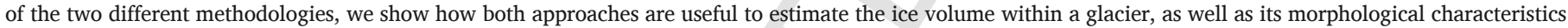

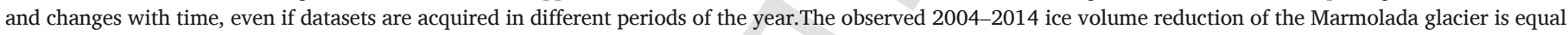

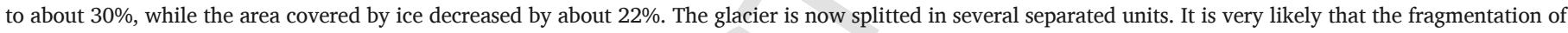

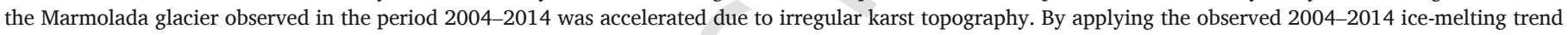

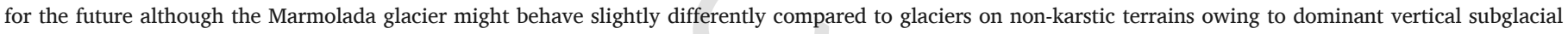

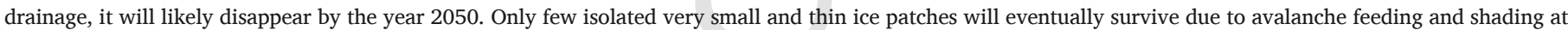
the foot of the north-facing cliffs.

\section{Introduction}

Glaciers are essential climate proxies, because they are very sensitive to climatic and environmental changes (Oerlemans, 2005). They react to external forcing by rapidly adjusting their shape and size and their evolution in time is extremely useful not only for glaciological studies and practical applications like e.g. hydrological modelling and touristic exploitation (Diolaiuti et al., 2006), but also for climate change assessment and future forecasts (Kaser et al., 2003; Zemp et al., 2013). Long-term glacier observation records are the basis for the understanding of physical processes leading to glaciers response to climatic change (Haeberli et al., 2013). In order to provide a worldwide collection of standardised data about glaciers' changes and validate models of the possible forecasted future warming, programmes and organisations such as "Global Land Ice Measurements from Space"
(GLIMS) and "World Glacier Monitoring Service" (WGMS) have allowed researchers to jointly collect data from across the globe (Haeberli et al., 2013; Zemp et al., 2008). In Italy, the Italian Glaciological Committee (CGI) has been monitoring selected Italian glaciers since the end of the 19th century by carrying out annual glaciological surveys. Although such a long record of measurements is a valuable source of information, it is unfortunately insufficient to quantify in detail the actual glacier evolution through time. Indeed, detailed information about volume and internal frozen units is required for any estimation of water equivalent and for a more realistic forecast of the future evolution of a glacier (Colucci et al., 2015). While measurements of terminus re-adjustment from fixed benchmarks are still carried out, surveys based on mass balance measurements are becoming increasingly common. The mass balance describes mass inputs and outputs during each glaciological (i.e. hydrological) year and represents direct response of a

* Corresponding author.

E-mail address: r.colucci@ts.ismar.cnr.it (R.R. Colucci) 
glacier to atmospheric conditions of a certain period (Zemp et al., 2008). It supplies a quantitative expression of mass changes through time, in terms of water equivalent (w.e.), i.e. the glaciological parameter assessing "how much water" is actually stored within a frozen body.

In order to calculate the glacier mass balance, different methods can be applied (Diolaiuti et al., 2001; Zemp et al., 2013; Beedle et al., 2014, Mercer, 2018): from direct measurements of ablation and accumulation at individual points and the interpolation between them (Kaser et al., 2003; Fisher, 2011) to indirect geodetic, as the use of satellite images and DEMs (Mercer, 2010; Zemp et al., 2010; Nistor, 2014), and geophysical methods (Pavan et al., 2000; Booth et al., 2013; Godio and Rege, 2015). One of the geophysical techniques to monitor the state and evolution of a glacier is the Ground Penetrating Radar (GPR) (Forte et al., 2014; Colucci et al., 2015; Dossi et al., 2016). This technique provides images of the internal structure of a glacier and allows calculation of the mass balance through time in case data from multiple surveys are available (Forte et al., 2014). The investigation depth reached by this technique in frozen materials is greater than in any other geological material owing to low electrical conductivity of ice, firn and snow, whereas a possibility to obtain high resolution imaging makes GPR an extremely effective tool in glaciological studies (Annan et al., 1994; Arcone et al., 1995). GPR surveys are applied in glaciology with different objectives, including ice volume estimation (Binder et al., 2009; Gabbi et al., 2012), imaging of the internal structure of a clean ice body (Arcone, 1996; Colucci et al., 2015) or covered by debris (e.g. Kozamernik et al., 2018), determination of the thermal regime (Bælum and Benn, 2011; Gacitùa et al., 2015) and quantification of snow seasonal melting and the characterization of the snow cover (Godio, 2009; Gusmeroli et al., 2014; Zhao et al., 2016). Moreover, there are several other specific glaciological applications spanning from sub-glacial lakes detection (Siegert et al., 2004) to discovery and characterization of brines (Forte et al., 2016) andice cave imaging (e.g. Hausmann and Behm, 2010; Colucci et al., 2016), as well as permafrost monitoring (Wu et al., 2005), among others. The use of GPR technique allows to characterize in detail the internal structure of ice bodies and to quantify its volumetric change through time, making possible to insert the local glacial variations in the wider context of global warming. One effect of the present global warming, which is the most evident for large and medium size glaciers, is the fragmentation of ice bodies due to repeated and consecutive negative mass balance. As a consequence, an increasing bedrock outcrop divides a single ice body in smaller parts, resulting at the end in the extinction of the whole glacier through time (Carturan et al., 2013a). This situation, in some cases, represents an obstacle to the continuation of long-term observations and it has been recently suggested, where possible, to start new observations on neighbouring glaciers located at higher altitude that have more likelihood of survival into the next few decades (Carturan, 2016). In addition to ice body fragmentation, another global-warming-related effect is the modification of the glacier geometry, mainly changes in convexity-concavity of the longitudinal profile (Scotti and Brardinoni, 2018). This, in turn, affects the net energy balance at a glacier surface and the accumulation and redistribution of snow by the wind (Hagg et al., 2017).

At present, most GPR surveys are performed using ground-coupled systems, moved along the survey area manually or using dedicated vehicles. Ground-based GPR surveys may have relevant logistical challenges on rough terrain, and particularly over glaciers due to the presence of crevasses and the inherent risk of landslides or avalanches. In these conditions, airborne GPR surveys may be preferable, since they allow safely operating, and rapidly surveying large areas. Even more important, airborne GPR glaciological surveys are quite common because they exploit the generally low electrical conductivity of frozen materials, which in turn makes possible to reach penetration depths not achievable in most of other geological materials. Most airborne GPR surveys are performed using helicopters, which exhibit a better mobility and have lower logistical constraints when compared to aircrafts. In fact, the high agility of helicopters allows following more complex and tortuous paths, reaching a higher spatial data density. Some recent papers compared the performances of conventional commercial GPR mounted under a helicopter with the ones obtained exploiting radar systems specifically developed for airborne surveys (Merz et al., 2015a; Rutishauser et al., 2016). They concluded that besides some minor differences, the two strategies produce comparable results in terms of the overall accuracy and attainable information. On the other hand, while some researchers concluded that airborne data quality outperforms the one of ground-based data sets (e.g. Merz et al., 2015b) other scholars reported opposite results (e.g. Rutishauser et al., 2016). In any case, the performances are strongly site-specific, also showing a significant dependency to temperature, water content and overall ice conditions, thus making such kind of comparisons inconclusive. In order to overcome such problems, we integrated two datasets acquired over the Marmolada glacier in the Dolomites (Italy) with different systems and/or by different platforms: the first was collected in 2004 with a ground based GPR equipment, the second in 2015 with a helicopter-borne GPR.

Despite long data series and high number of measurements, no precise volume variations in time are available for the Marmolada glacier. Such estimates are indeed essential to evaluate the change of water stored in the glacier and in turn make possible realistic forecasts of its availability (Bahr et al., 2015). This paper addresses in part this issue, trying also to obtain more general methodological achievements. The main aims of this work are: 1 ) to provide a multi-year geodetic mass balance of the Marmolada glacier within the 2004-2014 period through the comparison of two GPR datasets; 2) to create maps of ice thickness distribution in years 2004 and 2014 in order to highlight and discuss the fragmentation of the glacier, the change in its morphology and its relation with the bedrock; 3 ) to extrapolate some general methodological conclusions about ground and airborne based GPR surveys, the overall affordability of the results, and the possibility of integration with other techniques.

\subsection{Study area}

The Marmolada glacier $\left(46^{\circ} 26^{\prime} 32^{\prime \prime} \mathrm{N}, 11^{\circ} 51^{\prime} 53^{\prime \prime} \mathrm{E}\right)$ is located in the northeastern Italy. The glacier is included in the Italian Glacier Inventory since 1959 with ID 941 (Smiraglia and Diolaiuti, 2015). It is a hanging glacier overlying the northern slopes of Marmolada (Fig. 1; highest peak Punta Penìa, $3343 \mathrm{~m}$ ), the highest massif of the Dolomites (Eastern Alps). Marmolada massif is composed of massive Ladinian limestone, called Calcare della Marmolada, which belongs to the formation of Dolomia dello Sciliar (Antonelli et al., 1990).

The glacier accumulation area is restricted by a sharp mountain crest running from west to east. The glacier flux is directed toward north, at present descending only part of the way to the main valley. Two former nunataks, named Sasso delle Undici $(2770 \mathrm{~m})$ and Sasso delle Dodici $(2690 \mathrm{~m})$, divide the ablation area in three small fronts namely the eastern, the central and the western front. According to Smiraglia and Diolaiuti (2015) and due to the dramatic shrinking the Marmolada glacier has undergone since the 

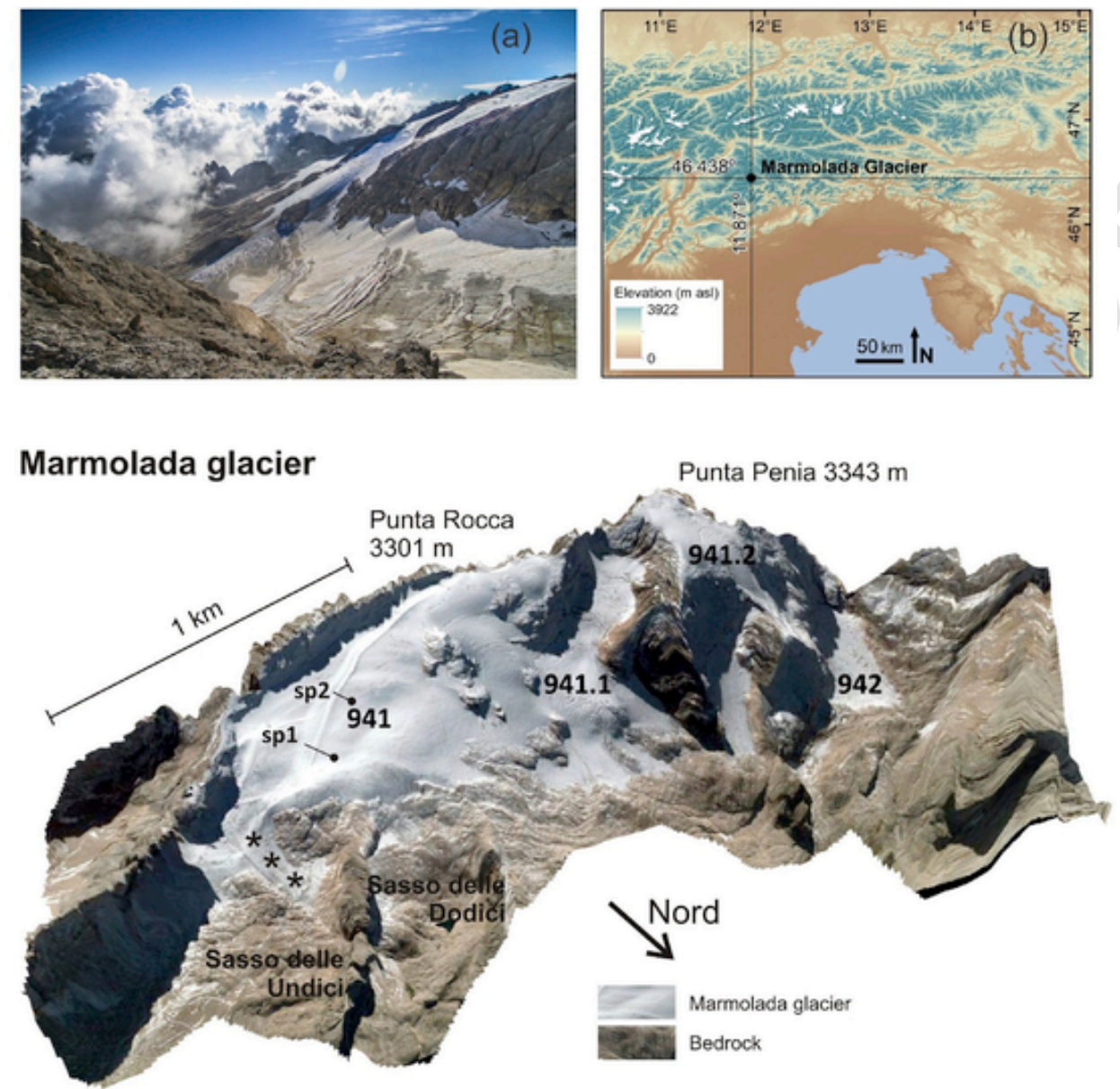

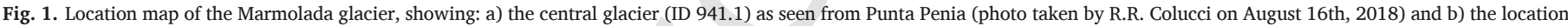

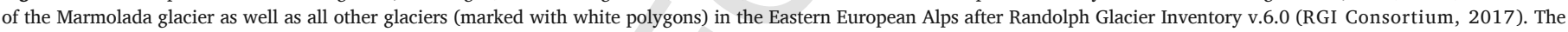

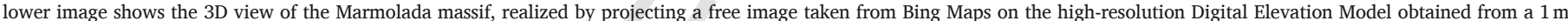

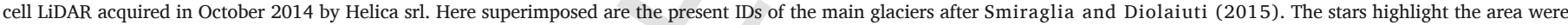
protective blankets are located during the summer months in order to prevent ice melting, whereas $s p 1$ and $s p 2$ show the location of the snow pits.

end of the Little Ice Age (LIA), but especially in the last 30 years, the glacier is divided in several sectors separated by rocky outcrops. The largest central sector is the Main Glacier (ID 941). Another sector is an isolated ice cap located on small plateau north of the highest summit of the Marmolada massif, the glacier of Punta Penìa (ID 941.2). Below Punta Penìa, there is the Central Glacier (ID 941.1) while the Western Glacier (ID 942) constitutes the westernmost part and was not considered in this study (Fig. 1). Part of the ID 941 glacier is interested by anthropic facilities and interventions, such as the ski run starting below Punta Rocca. Consequently, the slope of the glacier is modified in that sector. Moreover, white blankets are posed during summer to prevent ice melting and the degradation of the ski run in the easternmost sector of the glacier terminus (see Fig. 1), partially slowing down the retreat of the glacier in that small area. However, the effect of such mitigation strategy is negligible at the glacier scale and therefore it is not specifically considered in the present work.

Carton et al. (2017) recently reconstructed the areal changes of the Marmolada glacier since the end of the 19th century by combining aerial and satellite photographs, historical maps, and direct measurements. In 1888 , the glacier covered an area of $4.28 \mathrm{~km}^{2}$. Since the end of the LIA (approx. 1860) the glacier showed a quite continuous decreasing trend, similarly to all the other alpine glaciers. In the last century, the glacier advanced only during two short periods (1910-1920 and 1970-1980), similarly to what has been observed on other small glaciers and ice patches in the south-eastern Alps (Colucci and Žebre, 2016). In 2015, the Marmolada glacier covered $1.48 \mathrm{~km}^{2}$ (Carton et al., 2017) reducing its area by about $66 \%$ from first documented observations in 1888 . The glacier retreat is also shown by the analysis of terminus position, carried out by the CGI during annual glaciological surveys (e.g., Baroni et al., 2018). From 1971 to 2015 the fronts retreated several hundreds of meters, reaching $650 \mathrm{~m}$ in the central part. At the end of the last century, the glacier retreat underwent a progressive increase, reaching $30 \mathrm{~m}$ per year (Mattana and Varotto, 2010; Carton et al., 2017).

\section{Methods}

GPR is a geophysical non-invasive technique, which allows imaging the subsurface at high resolution and characterizing materials by their electromagnetic (EM) properties. It is based on the transmission of EM waves and on the registration of the travel time of the reflections generated by EM impedance contrasts between different materials (Jol, 2009). GPR has various fields of applications, especially in geology, archaeology and engineering. This technique is particularly efficient in glaciology, where frozen materials are characterized by low overall electrical conductivity, which allows the EM signal to limit its attenuation and to reach 
penetration depths of even hundreds of meters in favourable conditions. Penetration depth depends also on the frequency used, the free water content, the ice characteristics, the presence of debris, and the antenna-ground coupling. In glaciology, snow, firn and ice are distinguished by density. Density affects EM parameters like electrical conductivity and dielectric permittivity, in turn producing relevant changes of the subsurface EM velocity (Forte et al., 2013). Thus, in a GPR profile it is possible to identify the boundaries between different frozen layers because they exhibit different EM signatures. Pure ice is basically transparent from the EM point of view, while in snow (and somewhat in firn) the layering can be usually observed due to seasonal accumulation. In case of temperate glaciers, like the Marmolada glacier, the presence of free water generates dispersive phenomena, resulting in diffractions that can be observed along GPR profiles and usually produces an overall decrease of the signal-to-noise ratio. Most GPR surveys are performed with ground-coupled antennas, dragged directly on the surface both manually or using a dedicate vehicle. Planning a survey in remote locations, like many alpine cirque glaciers, involves important logistical challenges. The presence of crevasses and risk of avalanches represent threats to operators' safety. Moreover, if the investigation area is wide and a high spatial density of measures is mandatory, the survey time can be very long, also considering the unavoidable stops due to bad weather conditions. Airborne GPR surveys can be a valid solution, because they are less affected by terrain challenges and can rapidly cover extended areas, acquiring data up to several tens of kilometres per hour (Eisenburger et al., 2008; Gusmeroli et al., 2014; Merz et al., 2015b). In fact, airborne surveys have been performed since a long time using Radio Echo Sounding systems (e.g. Steenson, 1951; Cook, 1960), which are similar in principle to commercial GPR and are usually adopted in Arctic and Antarctic regions for ice sheet exploration and ice-bedrock interface detection (Hélière et al., 2007; Dall et al., 2010). A comprehensive review of such equipments, which are not the focus of this paper, is provided for instance by Plewes and Hubbard (2001). Further discussion about pros and cons of airborne GPR surveys can be found in Rutishauser et al. (2016) and Forte et al. (2019).

The first GPR dataset analyzed in this work was acquired on October 2nd and 3rd, 2004, using two different ground-coupled systems: a GSSI system equipped with a $35 \mathrm{MHz}$ antenna pair and a monostatic PulseEKKO 4 (Sensors\&Software) equipped with a $100 \mathrm{MHz}$ antenna. At the end of the survey, an irregular grid composed of 44 profiles with an overall length of $21.321 \mathrm{~km}$ was collected. After a preliminary quality control, only the most informative profiles having an overall length of $16.262 \mathrm{~km}$ were selected. The quality control focused on the identification of the boundary between ice and rock (i.e. glacier bed), usually characterized by a high reflectivity. We applied a standard processing flow, including zero-time correction, background removal, amplitude recovery, and velocity analysis by means of diffraction hyperbolas fitting. The mean EM velocity was estimated to $17 \mathrm{~cm} / \mathrm{ns}$, which equals the typical value for ice with negligible free water content. Then, we calculated the ice thickness along each profile and carefully checked the results at the crossing points.

The second GPR dataset was acquired on June 5th, 2015. This period of the survey was chosen in order to test the potential of the method described in Forte et al. (2014) by using a GPR system placed on a helicopter. The survey was carried out using a step frequency Hera-G system (Radar SystemTechnik-RST) equipped with a $100 \mathrm{MHz}$ antenna, based on step frequency system. Details on step-frequency systems and specifically about Hera-G radar can be found in Hamran et al. (1995) and Krellmann and Trilzsch (2012), respectively. The equipment was set on a frame and suspended below an Eurocopter AS350 helicopter with a $10 \mathrm{~m}$ long cable. The time window for the acquisition was set to $2225.09 \mathrm{~ns}$ with a sampling interval equal to $1.087 \mathrm{~ns}$. These setting resulted in a Nyquist frequency of $460 \mathrm{MHz}$, which is far higher than the highest frequency of the useful signal (about $160 \mathrm{MHz}$ ). A total of $83 \mathrm{~km}$ of profiles were acquired. After a careful editing and quality control, necessary to highlight, and when possible, correct errors due to airborne acquisition, only $22 \mathrm{~km}$ of profiles imaging snow/ice have been used for the interpretation. Further details and a discussion dedicated to logistical and technical constraints on data acquisition in rugged mountainous areas with a focus on the 2015 survey are provided by Forte et al. (2019). We applied a basic processing flow encompassing band-pass filtering, datuming, topographic (static) corrections considering the variable flight elevation above the ground for each trace, and exponential amplitude recovery. The amplitude recovery considers a constant attenuation equal to $0.2 \mathrm{~dB} / \mathrm{m}$, which is higher than pure ice, and qualitatively takes into account the presence of free water and the scattering events within the frozen materials. In addition to this geophysical survey, two $2.70 \mathrm{~m}$ deep snow pits (Fig. 1) were dugin order to determine the snow density of the winter snow cover at the date of the GPR survey. Using Looyenga empirical equation (Looyenga, 1965), which relates frozen materials density to EM parameters, we estimated the EM velocity. From a mean density value of $482 \mathrm{~kg} / \mathrm{m}^{3}$ within the snow pits, the velocity resulted equal to $21.2 \mathrm{~cm} / \mathrm{ns}$. A constant velocity of $17 \mathrm{~cm} / \mathrm{ns}$ was deduced for the ice by using diffraction hyperbolas fitting. All the 2004 and 2015 interpreted horizons using a semi-automated picking procedure of Petrel ${ }^{\circledR}$ Suite (Fig. 2) have been imported into GIS environment (QGis and Surfer - Golden Software) after depth conversion in order to better manage the interpolated surfaces. The errors in the horizons time picking are in general limited to few ns due to the overall high data quality of both the analyzed datasets and were carefully checked at all the crossing points. When larger discrepancies were present in particular in the 2015 survey, we decided to eliminate such data, as previously already pointed out. Local velocity variations are possible, so producing errors in the time-to-depth conversion step, but in present case such errors are always lower than $1 \mathrm{~m}$ as verified in the analysis of crossing points and cross-validation of the data.

During the gridding process we applied a Kriging algorithm preserving the original values at their own locations and obtaining a regular grid of square cells ( $20 \mathrm{~m}$ by $20 \mathrm{~m}$ ). We set the same border for the joining information from Pasta et al. (2005), Crepaz et al. (2013) and Carton et al. (2017). For the 2015 dataset we have not only reconstructed the glacier bed (Fig. 2b and c) but also the snow-ice horizon by subtracting the inferred snow thickness from the total thickness between the topographic surface and the glacier bed, as later on discussed. This processing was made possible due to the overall high quality and resolution of data, which allowed to clearly interpret the above described surface and even some other specific structures within the ice body.

\section{Results}

After data interpolation and gridding, we obtained the 2004 and 2014 ice thickness maps (Fig. 3). We highlight that the survey although performed in 2015, allows to infer the remaining ice thickness at the end of the 2014 glaciological year, and for this reason the comparison represents a 10-year-long evolution of ice volume. Therefore, for the sake of clarity, we hereafter refer to 2014 ice thickness as the result of the 2015 GPR survey analysis. Due to different spatial density of the two datasets (black and red lines 


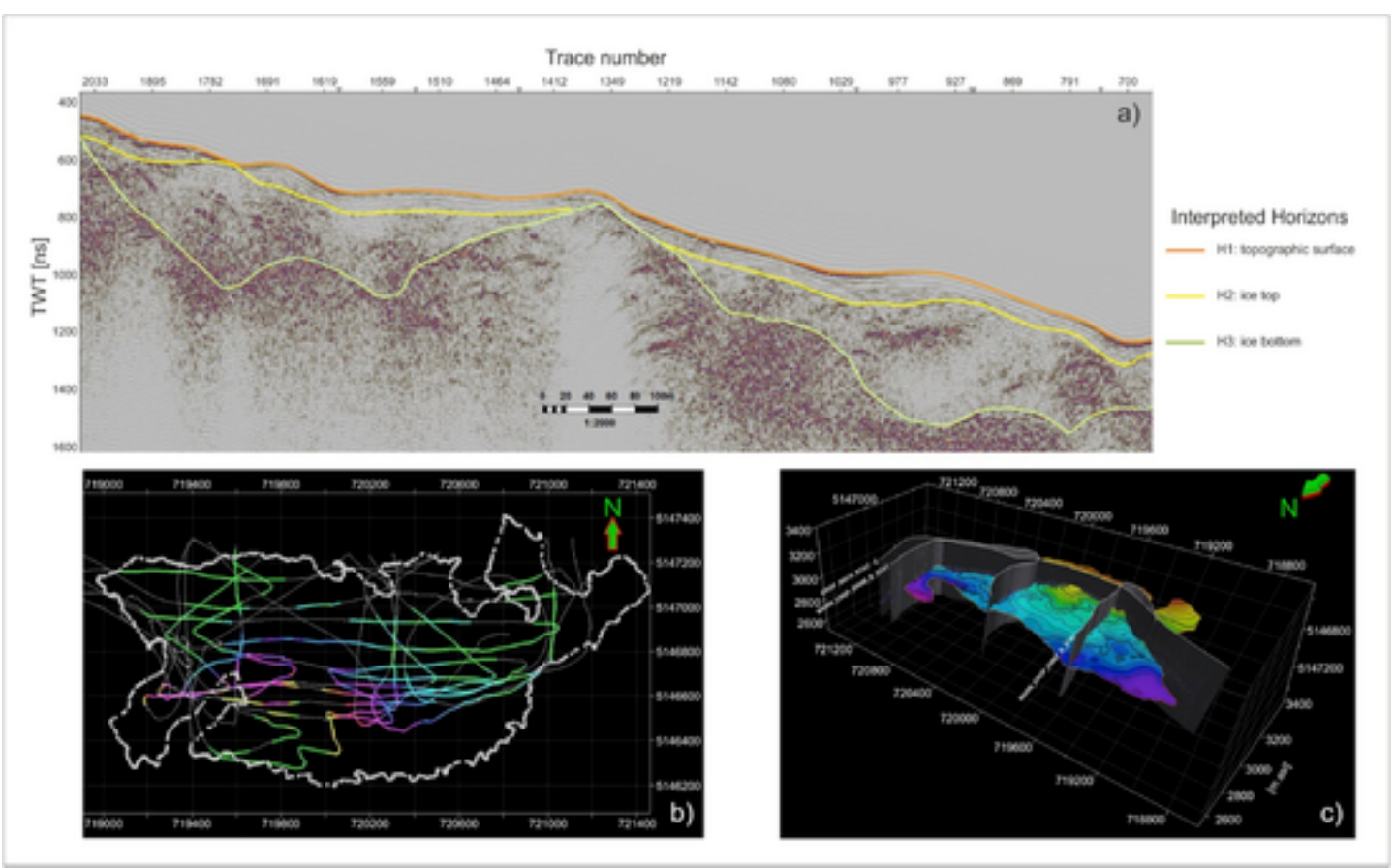

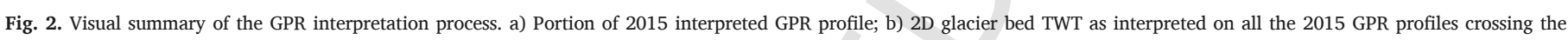
glacier; c) 3D view of the glacier bed interpolated surface, with three exemplary profiles.

in Fig. 3a and b, respectively), we excluded some areas from the analysis. These zones, located north-east and south-west of the glacier, are marked by green dashed polygons. Letter Z marks an unrealistically low ice thickness zone due to the lack of profiles acquired during the 2004 GPR survey. The same issue is apparent in the map provided by Pasta et al. (2005), as the analysis was performed on the same dataset. Analysing Fig. 3a, it was possible to estimate the mean thickness in 2004 , which was equal to $18.0 \mathrm{~m}$, while the maximum depths (equal to about $50 \mathrm{~m}$ and $40 \mathrm{~m}$ ) were located in the north-west and north-east border of the glacier, respectively. In 2014 (Fig. 3b), the average ice thickness was $12.9 \mathrm{~m}$, while the maximum thickness was calculated to about $40 \mathrm{~m}$. Because of the higher 2014 data coverage, the unrealistic $2004 \mathrm{Z}$-area revealed an ice thickness of $35 \mathrm{~m}$ in the map of 2014. In addition to thickness reduction, the glacier retreat between 2004 and 2014 is highlighted with black dashed zones in the ice thickness map (Fig. 3b), indicating the complete absence of any frozen material, as reported also by Carton et al. (2017). Table- 1 summarizes the estimated area, volume and w.e. derived from the two surveys. By comparing the 2004 and 2014 glacier snapshots, we observed not only a remarkable change of the area, but also, and even more relevant, a change of the glacier volume. Indeed, the volume (and so the w.e.) declined by $30 \%$, while the area covered by ice decreased by $22 \%$. Details of the ice thickness variations from 2004 to 2014 are shown in Fig. 4. The whole glacier underwent a decrease in ice thickness with a mean variation of about $5 \mathrm{~m}$, but with somehow unexpected different changes of its various portions. The maximum decrease in thickness, equal to about $25 \mathrm{~m}$, was reached in the eastern part of the glacier and in a small area toward west. In the northern sector the ice thickness variation is smaller (Fig. 4) but sufficient for bedrock outcropping and the formation of small nunataks. The outcropping area corresponds to the black dashed zone highlighted in Fig. 3b. In the central part of the Main Glacier (ID 941), an area of ice thickness variation on average below $7.5 \mathrm{~m}$ can be observed toward south, i.e. uphill. Out of this sector, the ice thickness variation is generally greater than $10 \mathrm{~m}$, locally up to $20 \mathrm{~m}$.

\section{Discussion}

The volume changes with time can be estimated by both photogrammetric and LiDAR techniques (Barrand et al., 2009), while the total volume of frozen materials and their characteristics are a more challenging issue. Despite the large number of GPR glaciological studies, the ones focusing on time monitoring of volumetric variations (i.e. 4D analyses) are still rare. In recent years, some examples have been proposed focusing both on ice caps (Saintenoy et al., 2013) and glaciers at different scales applying both terrestrial and airborne surveys (Navarro et al., 2005; Machguth et al., 2006; Forte et al., 2014; Colucci et al., 2015), but the full potential of GPR for glaciological monitoring is probably still unexploited (Del Gobbo et al., 2016).

Knowing in detail the actual area and volume of a glacier is in turn essential for the calculation of its mass and water equivalent. Using remote sensing data, such as aerial or satellite photographs, or LiDAR measurements, represent common techniques to obtain glacier outlines (Paul et al., 2013; Atwood et al., 2010), but there are specific issues to be taken into account. In particular, snapshots from the end of the ablation period with seasonal snow close to a minimum (Paul et al., 2013) are required in order to identify the ice limits without overestimations. Even with such favourable conditions, defining the actual ice limits is not always straightforward, especially where debris cover masks the ice or in areas where the transitions between ice, firn and snow are not clear. The observation time constraint of such techniques can be overcome by GPR surveys because ice, even when hidden below thick snow layers, can be detected relatively easily due to different EM signature with respect to the snow, in turn making possible accurate ice thickness estimation in any period of the year (e.g. Del Gobbo et al., 2016). Moreover, ice can be detected also under a debris cover, which is particularly convenient for mapping rock glaciers (Bernard et al., 2013) or debris inside glaciers, 

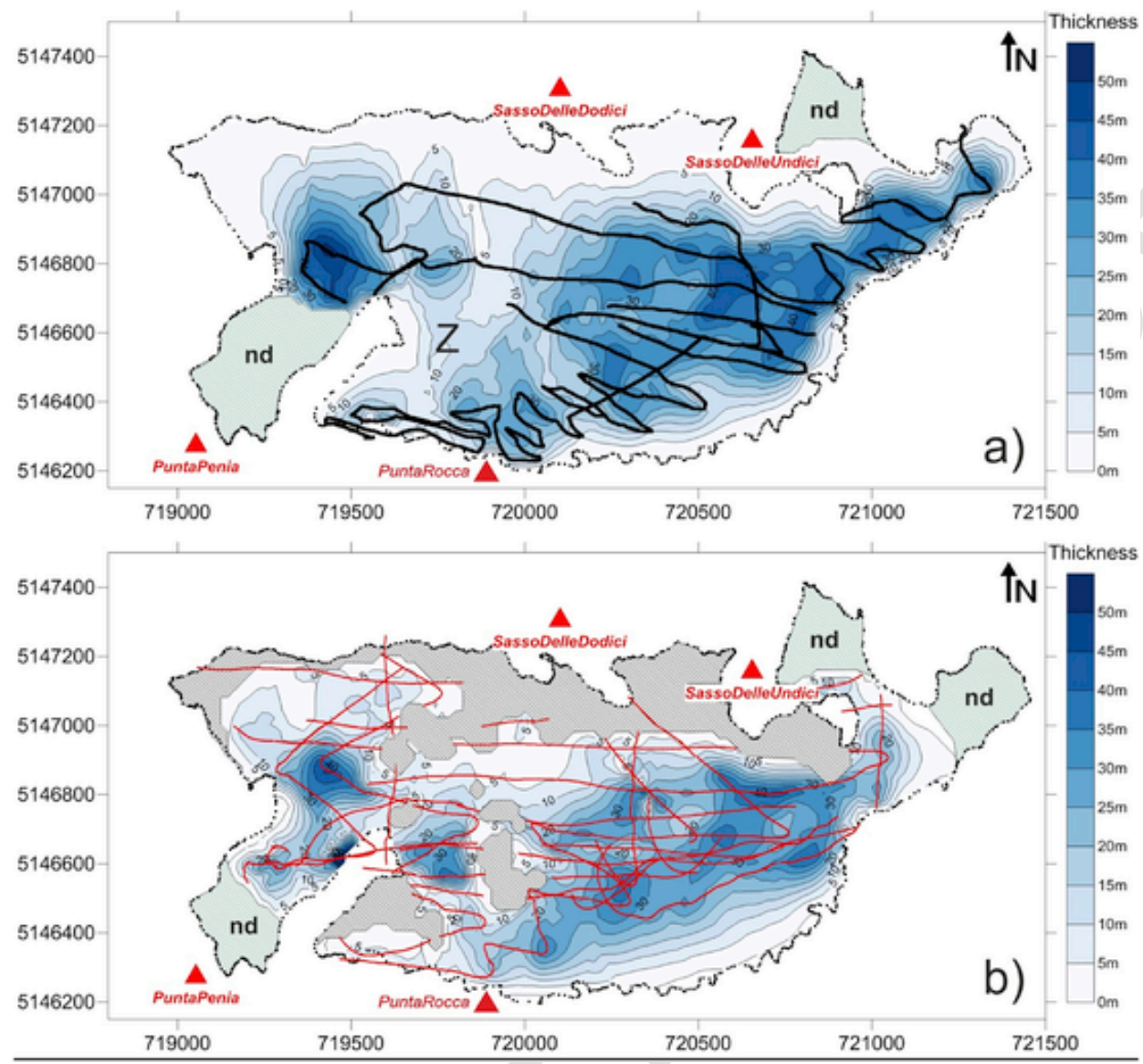

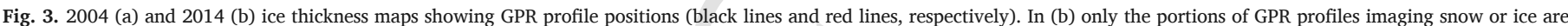

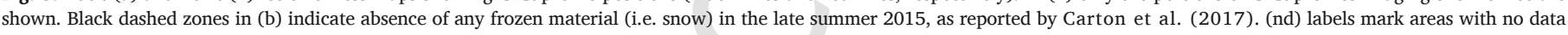

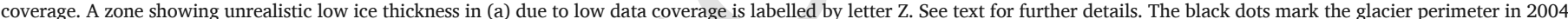

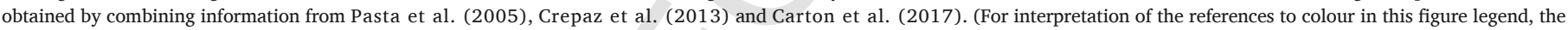
reader is referred to the Web version of this article.)

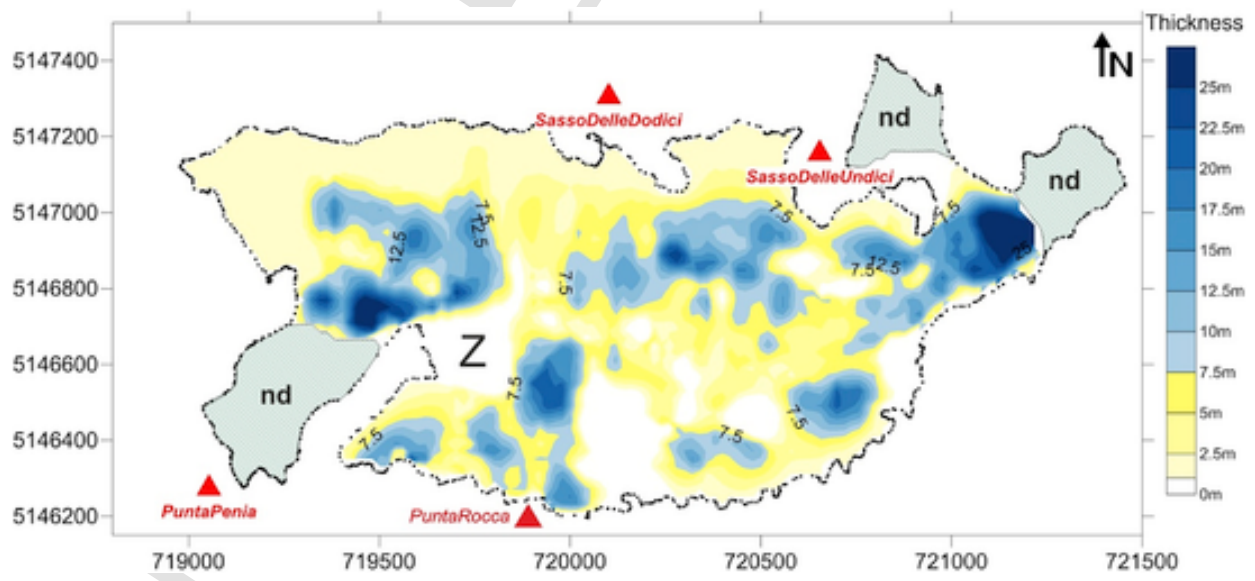

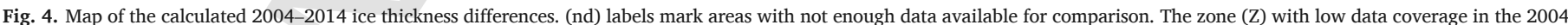
survey (See also Fig. 3) was blanked.

thus also improving ice volume estimates (Colucci et al., 2015). In addition, recognizing the snow layer allows to consider it for the w.e. calculation, hence obtaining a more realistic estimation of the water actually stored within the glacier. Fig. 5 shows the snow cover map derived from 2015 GPR survey. It is worth noting that the snow cover thickness was irregular, without any simple trend. As expected, the snow thickness was in general higher uphill, exceeding $10 \mathrm{~m}$ in the central part of the Main Glacier, while all the zones close to the front had a thickness lower than $5 \mathrm{~m}$. This distribution is likely related to several factors: 1) the partitioning between rain and snow during the accumulation season; 2) the temperature lapse rate with altitude; 3) the snow redistribution by the wind; 4) the avalanche feeding in the upper part of the glacier close to the cliffs. Moreover, the zones imaged either without any frozen 


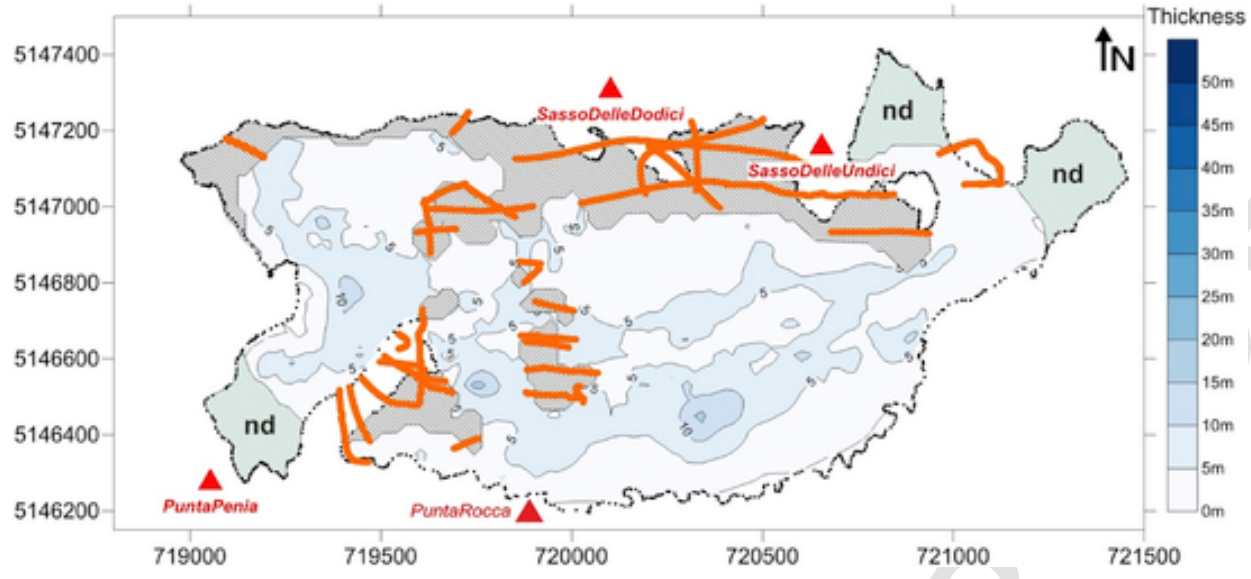

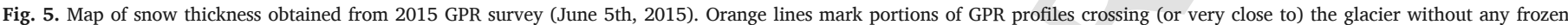

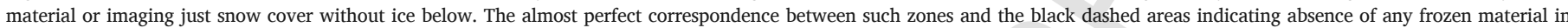

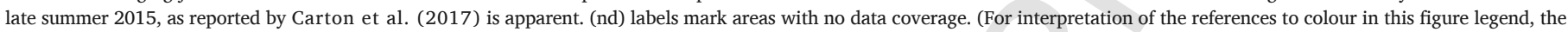
reader is referred to the Web version of this article.)

material, or just characterized by a snow cover without any ice below (orange lines in Fig. 5) that were extracted from GPR data analysis, almost perfectly match the zones without any frozen material (i.e. with rocks or debris outcropping) in late 2015 summer that were independently derived from aerial photographs by Carton et al. (2017). This demonstrates that GPR can be used not only to recover the ice volume in any period of the year, but also to image and discriminate between different frozen materials, which is in turn essential for quantitative glaciological studies.

In order to highlight the reduction of the Marmolada glacier in the period between 2004 and 2014, we drew attention to the $15 \mathrm{~m}$ ice thickness line (15L) along the ablation area of the Main Glacier. In Fig. 6 such thickness value is marked by green and yellow dashed lines for 2004 and 2014, respectively. In this 11-year period corresponding to 10 glaciological years (2004-2014), the 15L retreated uphill for about $90 \mathrm{~m}$ and the ablation area changed from an evident convex shape in 2004 to a partially concave shape in 2014. In Fig. 6c, we can observe that the southern part of the Main Glacier (within an area of about $430 * 10^{3} \mathrm{~m}^{2}$ ) shows thickness variations on average lower than $7.5 \mathrm{~m}$. By comparing this areal value with the one reported in Table- 1 , which encompasses also other portions, it can be noted that the surface decrease is higher than $22 \%$, actually exceeding $60 \%$. In fact, by analysing Fig. 6 , we noticed that while in 2004 the glacier was a single ice body (Fig. 6a), in 2014 it disintegrated into three almost separated ice bodies (the MG and the two glaciers below Punta Rocca and Punta Penìa in Figs. 6b and $7 b)$.

By integrating the GPR survey with the available 2014 LiDAR survey, it is possible to reconstruct the elevation changes along the glacier. For 2004 no LiDAR data were available, but it was still possible to calculate the topographic surface elevation by adding the ice thickness in 2004 to the elevation of the bedrock (obtained from the 2015 GPR dataset). From 2004 to 2014 the glacier was interested by large changes in morphology and hypsometry (Fig. 7). Consequently, wind drifted snow now tends to accumulate more in the median and higher sector of the glacier, which could locally increase the accumulation rate in the future. This would be in agreement with what has been observed on some maritime glaciers in the Central Alps by Scotti and Brardinoni (2018). There, a climate-glacier decoupling leading to positive feedbacks in the snow accumulation pattern controlled by geomorphological changes in the convexity-concavity of the longitudinal profile led to a progressive increase in the amount of winter snow accumulated due to wind drift processes and avalanches. In this context, the recent abrupt modification of the Marmolada glacier might be seen as a change also in its behaviour. The Marmolada glacier is splitting in rather smaller glaciers that will soon likely become glacial ice patches (sensu Serrano et al., 2011). Therefore, these presently shrinking ice bodies are acquiring some of the peculiarities associated with those end-member type of glaciers more resilient to the recent climate warming, especially in areas with high MAP (Carturan et al., 2013b; Colucci and Guglielmin, 2015; Colucci, 2016; Scotti and Brardinoni, 2018).

Longer and warmer summers are strongly affecting the ablation season, which often reflects in earlier winter snow melting from most of the glacier surface (Fig. 7b). This is producing an accelerated retreat also due to change in albedo feedbacks. Moreover, increased portions of rocky outcrops in several parts of the glacier act as source of longwave radiation, which produces further heating. Although important heat waves with temperature anomaly greater than 3 standard deviations from the 1971-2000 mean has been recorded both in summer and in winter (Colucci et al., 2017), the winter seasons 2008-2009 and 2013-2014 produced winter snow accumulation much higher than the average, able to influence the ice patches and very small glaciers for several years (Colucci, 2016). In the Italian Prealps a series of positive annual mass balance years was observed on few small maritime glaciers (Carturan et al., 2013a; Scotti et al., 2014; Colucci et al., 2015; Colucci and Guglielmin, 2015; Scotti and Brardinoni, 2018). The same behavior was not only common for these prealpine glaciers, but also for some very small Mediterranean glaciers (Hughes, 2014, 2018) as is the case of Durmitor in Montenegro (Hughes, 2007), Prokletije mountains in Albania (Hughes, 2009) and Pirin mountains in Bulgaria (Nojarov et al., 2019). This behave apparently not in agreement with the ongoing climate warming and the response of the vast majority of all alpine glaciers (Zemp et al., 2008), seems to be mainly related to change in the geometry of such ice bodies and precipitation variability.

Marmolada is a glacier resting on permeable carbonate rocks (Calcare della Marmolada) where the karst morphology affected by subglacial erosion has developed. In several alpine areas, the combined action of glacial and fluvial erosion has formed the landscape, whereas in karst areas, most water drains underground. As a result, glacial landforms are normally less reworked by flowing waters and the effect of pure subglacial erosion can be observed (Gremaud and Goldscheider, 2010). In Fig. 8 the topography of the Marmolada glacier bed with a $20 \times 20 \mathrm{~m}$ cell size, was 

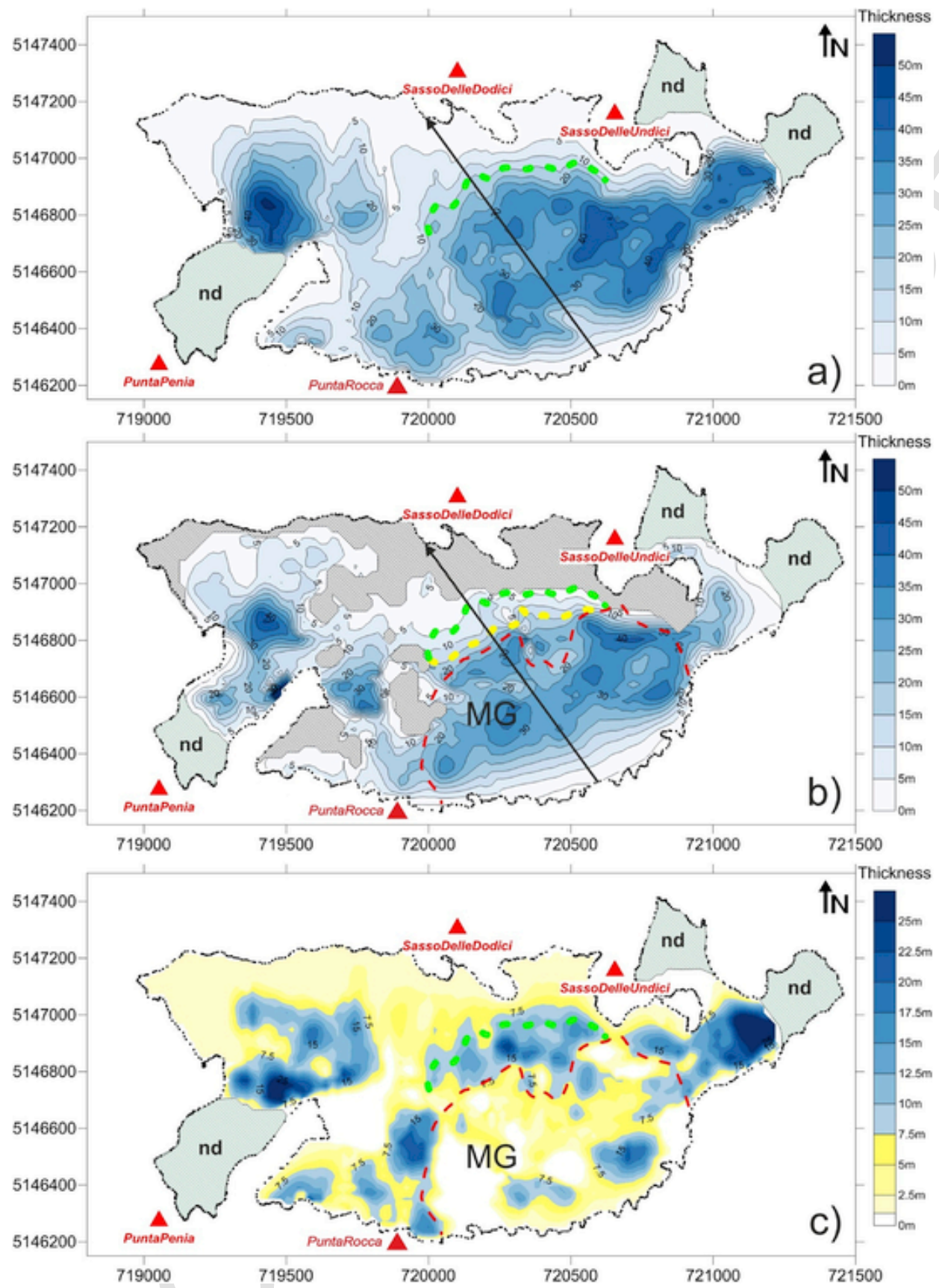

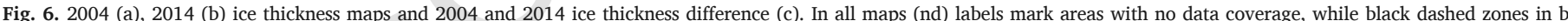

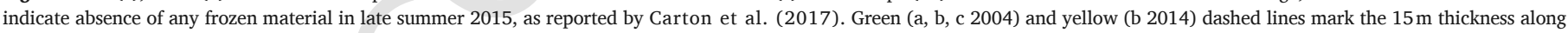

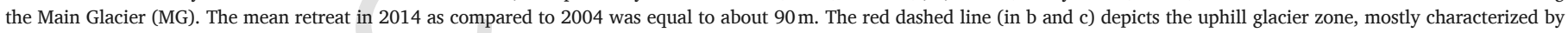
differences lower than $7.5 \mathrm{~m}$. See text for the discussion. (For interpretation of the references to colour in this figure legend, the reader is referred to the Web version of this article.)

obtained by subtracting the ice thickness inferred by 2004 ground based GPR data from the elevation measured along the GPR profiles. This was done in combination with data resulting by subtracting the whole thickness of frozen materials (inferred from helicopter-borne survey) from 2015 surface topography. The two independent results for 2004 and 2015 are in good agreement, suggesting that both ground based and helicopter-borne GPR surveys are equally effective in the glacier bed imaging. In detail, the Marmolada glacier bed morphology consists of depressions and mounds (Fig. 8), which resemble the karst landscape immediately below the glacier front and also further down in the glacier forefield that has been exposed since the LIA.
In this area, depressions are up to a few hundred of metres wide and tens of metres deep, some of them are enclosed by steep walls, suggesting a quarrying-dominated subglacial erosion. Similar irregular bed morphologies have been described from other glaciers resting on permeable carbonate lithologies, such as Tsanfleuron glacier in Switzerland (Sharp et al., 1989; Gremaud and Goldscheider, 2010), Canin Eastern glacier in Italy (Colucci et al., 2015), glaciers in the Canadian Rocky Mountains (Ford, 1983; Smart, 1996). Although the geologic influence on glacier motion and overall glacier response to climate change is still not well understood, we assume that the fragmentation of the Marmolada 
Table-1

Synthesis of 2004 and 2014 calculated areas, ice volumes and w.e. of the Marmolada glacier.

\begin{tabular}{llll}
\hline & 2004 & 2014 & $\begin{array}{l}\text { Percentage } \\
\text { variation }\end{array}$ \\
\hline AREA & $1402000 \mathrm{~m}^{2}$ & $1097000 \mathrm{~m}^{2}$ & $-22 \%$ \\
ICE VOLUME $^{\text {WATER }}$ & $25267000 \mathrm{~m}^{3}$ & $17499000 \mathrm{~m}^{3}$ & $-30 \%$ \\
EQUIVALENT $^{\text {a }}$ & $16.2 \mathrm{~m}$ & $11.5 \mathrm{~m}$ & $-30 \%$ \\
\hline
\end{tabular}

a Considering an ice density equal to $900 \mathrm{kgm}^{-3}$ and the 2004 area.

glacier observed since the LIA, but especially in the period 2004-2014 and in general in the last decades, was accelerated due to irregular karstic topography. Another important aspect is the influence of rock permeability on subglacial hydrology and the contribution of glacier melt to stream runoff. While it is important to evaluate the w.e. of a glacier in the context of the future water availability, one should also consider the dispersive drainage paths peculiar of karstic terrains. The surface runoff network in the Marmolada glacier forefield is poorly developed, even during the melting season, when meltwater discharge is at its peak. This suggests that a great part of the meltwaters drains into the underlying karst underneath the glacier, which was also proposed paleoglaciers in a Mediterranean mountain karst (Adamson et al., 2014; Žebre and Stepišnik, 2015. Fedaia spring located at $2050 \mathrm{~m}$ a.s.l north of the glacier is probably the main drainage point of the Marmolada glacier (Dipartimento Territorio, Agricoltura, Ambiente e Foreste, 2015), although, to our knowledge, no dye tracing has been performed yet. This is indeed a critical point to be addressed in the future along with in-depth investigation of the rapidly deglaciating forefield forced by abrupt climate change. If the Marmolada glacier keeps reducing its volume at the same rate as observed in the 10 analyzed glaciological years, (i.e. about $750 \cdot 10^{3} \mathrm{~m}^{3}$ /year, Table- 1 ), it will likely disappear by 2050 , eventually resulting in just a few isolated ice patches controlled by local topography such as at the foot of north-facing cliffs or hollows, where higher accumulation is granted by avalanches and wind-blown snow (Grunewald and Scheithauer, 2010). The current snapshot of how could the Marmolada glacier appear in 30 years from now, can be found in the appearance of the present ice patches of the Julian Alps, such as in the area of Mount Canin and Triglav (Triglav Čekada et al., 2014; Colucci and Žebre, 2016).

\section{Conclusion}

We analyzed and integrated a ground based GPR survey collected on the Marmolada glacier in 2004 and a helicopter-
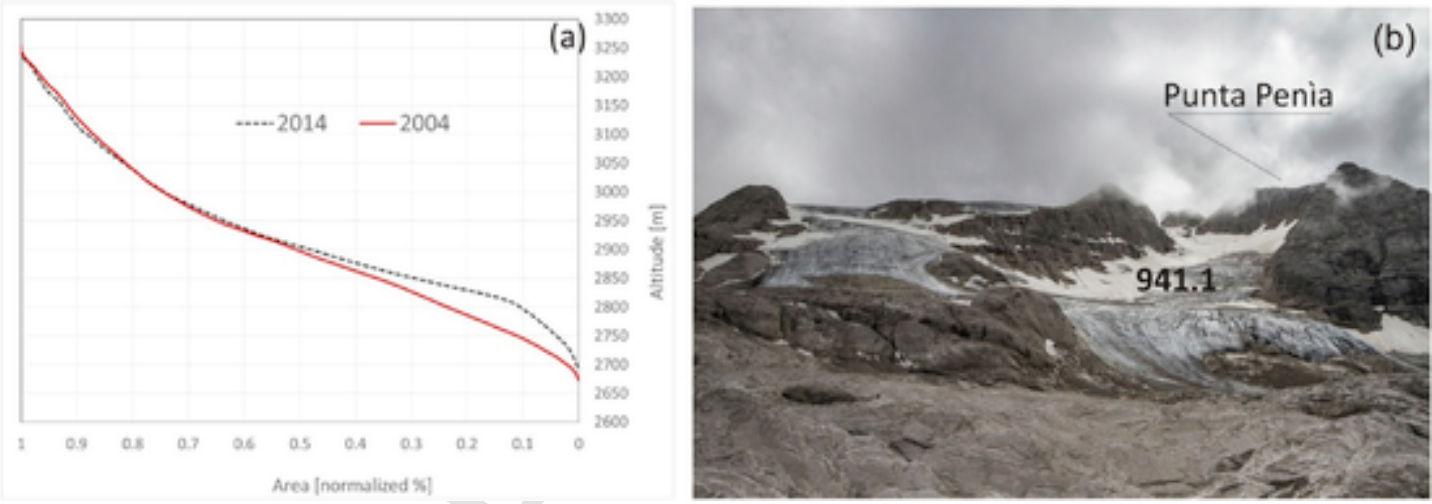

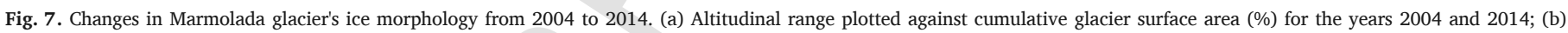

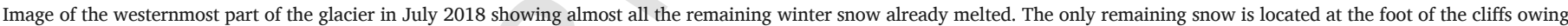
the increased avalanche accumulation.

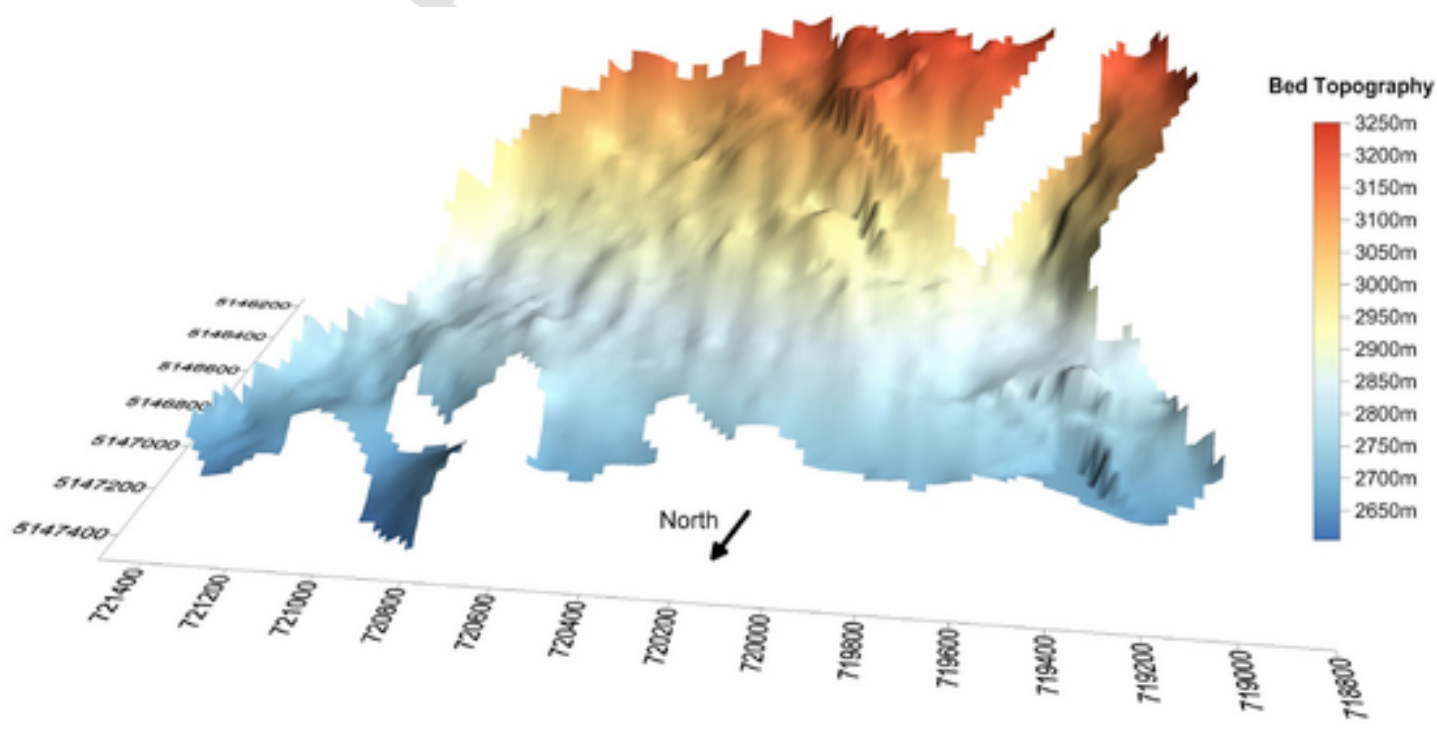

Fig. 8. Bed morphology of the Marmolada glacier inferred by combined GPR data sets. 
borne survey performed in 2015. Both approaches are useful for estimating the volume of the glacier as well as its morphological characteristics.

We estimate the mean ice thickness in 2004 to $18.0 \mathrm{~m}$, with a maximum close to $50 \mathrm{~m}$. In 2014 the average ice thickness decreased to $12.9 \mathrm{~m}$, while the maximum thickness lowered to about $40 \mathrm{~m}$. By integrating the two data sets, we observe a volume reduction equal to $30 \%$, while the area covered by ice decreased by $22 \%$, with new ice-free zones in 2014 not only related to the retreat of the front, but also within the glacier area. This caused a division of the previously unified glacier in separated ice bodies especially in its western part. If the Marmolada Glacier keeps reducing its volume at the same estimated rate of the 10 glaciological years analyzed (2004-2014), it will likely disappear by the year 2050 (i.e. in 25-30 years from now). Few small ice patches fed by avalanches at the foot of the northern cliffs and at the highest elevation of the massif will eventually represent the residual Marmolada glacier. However, karst morphology and drainage of subglacial waters could result in a slightly different behavior of the glacier compared to non-karstic landscapes, but the relationship between glaciers and karst is still not fully understood. This is a critical point to be considered in future studies, since it has implications not only for the limited number of still surviving glaciers on Alpine and Mediterranean limestone terrains, but also for paleoglaciers resting on carbonate lithologies in the Mediterranean region (e.g. Picos de Europa, Taurus Mountains, Dinaric Mountains), which were important component of the Pleistocene cryosphere.

GPR demonstrated its high versatility and applicability along the whole glaciological year. On the contrary, photogrammetric and LiDAR measurements, in order to be meaningful for glaciological purposes, should be performed only at the end of the ablation season and shortly before the first winter snowfall. We have shown how GPR can overcome such limitation, because it permits to discriminate and characterize not only different frozen materials, but also the presence of debris both within and above the glacier, in turn allowing to estimate the ice thickness (and volume) in any period of the year.

\section{Authors contribution}

RRC and EF conceived and led this study. IS and EF wrote the manuscript with the contribution of RRC and MZ. MP processed and interpreted the 2004 dataset, while IS and EF the 2015 one, also making their integration and comparison. The figures have been prepared by IS, RRC, EF and MZ. AC supported the field and logistic operations. All the authors participated in the discussion and revision of the final version of the manuscript.

Part of the results are reported in a Master Degree thesis in Geosciences (in Italian) discussed by IS at the University of Trieste in 2018 and entitled "Analysis and comparison of Ground Penetrating Radar (2004 and 2015) ground and helicopter based to estimate the ice volume evolution of the Marmolada glacier (Eastern Alps)". Supervisor EF, co-supervisor RRC.

\section{Uncited references}

\section{Carturan et al., 2016, Territorio, 2015}

\section{Acknowledgments}

We thank the management of Helica srl (Amaro, Italy) for the permission to use and publish the airborne GPR data set and we gratefully acknowledge Schlumberger through the University of Trieste Petrel ${ }^{\circledR}$ interpretation package academic grant. This project has received funding from the European Union's Horizon 2020 research and innovation programme under the Marie Sklodowska-Curie grant agreement No 793403 as well as from the "Progetti di Ricerca di Rilevante Interesse Nazionale - PRIN 2015", grant number 2015N8F555.

Authors are also thankful to the Editor in Chief and Guest Editor Emilio Chuvieco, to Philip Hughes, and to other two anonymous reviewers for providing thoughtful and useful comments and suggestions.

\section{References}

Adamson, K.R., Woodward, J.C., Hughes, P.D., 2014. Glaciers and rivers: Pleistocene uncoupling in a Mediterranean mountain karst. Quat. Sci. Rev. 94, 28-43. doi:10.1016/ j.quascirev.2014.04.016.

Annan, A.P., Cosway, S.W., Sigurdsson, T., 1994. GPR for Snow Water Content. Fifth International Conference on GPR. Waterloo Centre for Groundwater Research, University of Waterloo, Ontario, Canada, pp. 465-475.

Antonelli, R., Barbieri, G., Dal Piaz, G.V., Dal Pra, A., De Zanche, V., Grandesso, P., Mietto, P., Sedea, R., Zanferrari, A., 1990. Carta Geologica del Veneto 1:250000 una storia di cinquecento milioni di anni. Università degli Studi di Padova. (in Italian).

Arcone, S.A., 1996. High resolution of glacial ice stratigraphy: a ground-penetrating radar study of Pegasus Runway, McMurdo Station, Antarctica. Geophysics 61, 1653-1663.

Arcone, S.A., Lawson, D.E., Delaney, A.J., 1995. Short-pulse radar wavelet recovery and resolution of dielectric contracts within englacial and basal ice of Matanuska Glacier, Alaska, USA. J. Glaciol. 41, 68-86.

Atwood, D.K., Meyer, F., Arendt, A., 2010. Using L-band SAR coherence to delineate glacier extent. Can. J. Remote Sens. 36, 186-195.

Bahr, D.B., Pfeffer, W.T., Kaser, G., 2015. A review of volume-area scaling of glaciers. Rev. Geophys. 53, 95-140.

Baroni, C., Bondesan, A., Carturan, L., Chiarle, M., 2018. In: Report of the Glaciological Survey of 2017, vols. 41-2. Geografia Fisica e Dinamica Quaternaria, pp. 115-193.

Barrand, N., Murray, T., James, T., Barr, S., Mills, J., 2009. Optimizing photogrammetric DEMs for glacier volume change assessment using laser-scanning derived ground-control points. J. Glaciol. 55, 106-116.

Beedle, M.J., Menounos, B., Wheate, R., 2014. An evaluation of mass-balance methods applied to Castle Creek Glacier, British Columbia, Canada. J. Glaciol. 60, 262-276.

Bernard, E., Friedt, J.M., Saintenoy, A., Tolle, F., Griselin, M., Marlin, C., 2013. Where does a glacier end? GPR measurements to identify the limits between valley slopes and actual glacier body. Application to the Austre Lovénbreen, Spitsbergen. Int. J. Appl. Earth Obs. Geoinf. 27, 100-108.

Binder, D., Brückl, E., Roch, K.H., Behm, M., Schöner, W., Hynek, B., 2009. Determination of total ice volume and ice-thickness distribution of two glaciers in the Hohe Tauern region, Eastern Alps, from GPR data. Ann. Glaciol. 50, 71-79.

Booth, A.D., Mercer, A., Clark, R., Murray, T., Jansson, P., Axtell, C., 2013. A comparison of seismic and radar methods to establish the thickness and density of glacier snow cover. Ann. Glaciol. 54, 73-82.

Bælum, K., Benn, D.T., 2011. Thermal structure and drainage system of a small valley glacier (Tellbreen, Svalbard), Investigated by ground penetrating radar. Cryosphere 5 , 139-149.

Carton, A., Bondesan, A., Benetton, S., 2017. Marmolada, la regina della Dolomiti, Itinerari Glaciologici sulle Montagne Italiane 3. Itinerari 19A e 19B, pp. 189-212. (in Italian).

Carturan, L., 2016. Replacing monitored glaciers undergoing extinction: a new measurement series on La Mare Glacier (Ortles-Cevedale, Italy). J. Glaciol. 62, 1093-1103.

Carturan, L., Baroni, C., Becker, M., Bellin, A., Cainelli, O., Carton, A., Casarotto, C., Dalla Fontana, G., Godio, A., Martinelli, T., Salvatore, M.C., Seppi, R., 2013. Decay of a long-term monitored glacier: careser glacier (Ortles-Cevedale, european Alps). Cryosphere 7, 1819-1838.

Carturan, L., Baldassi, A.B., Bondesan, A., Calligaro, S., Carton, A., Cazorzi, F., Dalla Fontana, G., Francese, R., Guarnieri, A., Milan, N., Moro, D., Tarolli, P., 2013. Current behaviour and dynamics of the lowermost Italian glacier (montasio occidentale, julian Alps). Geogr. Ann. Ser. A Phys. Geogr. 95, 79-96.

Carturan, L., Baroni, C., Brunetti, M., Carton, A., Dalla Fontana, G., Salvatore, M.C. Zanoner, T., Zuecco, G., 2016. Analysis of the mass balance time series of glaciers in the Italian Alps. Cryosphere 10, 695-712.

Colucci, R.R., 2016. Geomorphic influence on small glacier response to post Little Ice Age climate warming: Julian Alps, Europe. Earth Surf. Process. Landforms 41, 1227-1240.

Colucci, R.R., Guglielmin, M., 2015. Precipitation-temperature changes and evolution of a small glacier in the southeastern European Alps during the last 90 years. Int. J. Climatol. 35, 2783-2797.

Colucci, R.R., Žebre, M., 2016. Late Holocene evolution of glaciers in the southeastern Alps. J. Maps 12, 289-299.

Colucci, R.R., Forte, E., Boccali, C., Dossi, M., Lanza, L., Pipan, M., Guglielmin, M., 2015. Evaluation of internal structure, volume and mass of glacial bodies by integrated LiDAR and ground 
penetrating radar (GPR) surveys: the case study of Canin Eastern Glacieret (Julian Alps, Italy). Surv. Geophys. 36, 231-252.

Colucci, R.R., Fontana, D., Forte, E., Potleca, M., Guglielmin, M., 2016. Response of ice caves to weather extremes in the Southeastern Alps, Europe. Geomorphology 261, $1-11$.

Colucci, R.R., Giorgi, F., Torma, C., 2017. Unprecedented heat wave in December 2015 and potential for winter glacier ablation in the eastern Alp. Sci. Rep. 7, 7090.

Cook, J.C., 1960. Proposed monocycle pulse VHF radar for airborne ice and snow measurement. Transactions of the American Institute of Electrical Engineers Part I (Communications and Electronics) 79, 588-594.

Crepaz, A., Cagnati, A., De Luca, G., 2013. Evoluzione dei ghiacciai delle Dolomiti negli ultimi cento anni e recenti bilanci di massa in tre apparati glaciali. Neve e Valanghe 80. (in Italian).

Dall, J., Kristensen, S.S., Krozer, V., Hernández, C.C., Vidkjær, J., Kusk, A., Balling, J., Skou, N., Søbjærg, S.S., Christensen, E.L., 2010. ESA's polarimetric airborne radar ice sounder (POLARIS): design and first results. IET Radar, Sonar Navig. 4 (3), 488-496.

Del Gobbo, C., Colucci, R.R., Forte, E. Triglav Cekada, M., Zorn, M., 2016. The Triglav Glacier (South-Eastern Alps, Slovenia): volume estimation, internal characterization and 2000-2013 temporal evolution by means of GPR measurements. Pure Appl. Geophys. 173, 2753-2766.

Diolaiuti, G., D’Agata, C., Pavan, M., Vassena, G., Lanzi, C., Pinoli, M., Pelfini, M., Pecci, M., Smiraglia, C., 2001. The physical evolution of and the anthropic impact on a glacier subjected to a high influx of tourist: vedretta Piana Glacier (Italian Alps). Geogr. Fis. Din. Quaternaria 24, 199-201.

Diolaiuti, G., Smiraglia, C., Pelfini, M., Belò, M., Pavan, M., Vassena, G., 2006. The recent evolution of an alpine glacier used for summer skiing (Vedretta Piana, Stelvio Pass, Italy). Cold Reg. Sci. Technol. 44, 206-216.

Dossi, M., Forte, E., Pipan, M., Colucci, R.R., Bortoletto, A., 2016. Automated reflection picking and inversion: application to ground and airborne GPR surveys. In: $16^{\text {th }}$ International Conference on Ground Penetrating Radar (GPR). pp. 1-6. Hong Kong

Eisenburger, D., Lentz, H., Jenett, M., 2008. Helicopter-borne GPR systems: away from ice thickness measurements to geological applications. Proceedings of the International Conference on Ultra-Wideband 3.

Fisher, A., 2011. Comparison of direct and geodetic mass balances on a multi-annual time scale. Cryosphere 5, 107-124.

Ford, D.C., 1983. The physiography of the castleguard karst and columbia icefields area, alberta, Canada. Arct. Alp. Res. 15, 427-436.

Forte, E., Dossi, M., Colucci, R.R., Pipan, M., 2013. A new fast methodology to estimate the density of frozen materials by means of common offset GPR data. J. Appl. Geophys. 99, 135-145

Forte, E., Dossi, M., Colle Fontana, M., Colucci, R.R., 2014. 4D Quantitative GPR Analyses to Study the Summer Mass Balance of a Glacier: a Case History. 15th International Conference on Ground Penetrating Radar, Brussels. GPR 2014.

Forte, E., Dalle Fratte, M., Azzaro, M., Guglielmin, M., 2016. Pressurized brines in Continental Antarctica as possible analog of Mars. Sci. Rep. 6, 33158

Forte, E., Basso Bondini, M., Bortoletto, A., Dossi, M., Colucci, R.R., 2019. Pros and cons in helicopter-borne GPR data acquisition on rugged mountainous areas: critical analysis and practical guidelines. Pure Appl. Geophys. 1-22. doi:10.1007/ s00024-019-02196-2.

Gabbi, J., Farinotti, D., Bauder, A., Maurer, H., 2012. Ice volume distribution and implications on runoff projections in a glacierized catchment. Hydrol. Earth Syst. Sci. 16, $4543-4556$.

Gacitùa, G., Uribe, J.A., Wilson, R., Loriaux, T., Hernàndez, J., Rivera, A., 2015. 50MHz helicopter-borne radar data for determination of glacier thermal regime in the central Chilean Andes. Ann. Glaciol. 56, 193-201.

Godio, A., 2009. Georadar measurements for the snow cover density. Am. J. Appl. Sci. 6, 414-423.
Godio, A., Rege, R.B., 2015. The mechanical properties of snow and ice of an alpine glacier inferred by integrating seismic and GPR methods. J. Appl. Geophys. 115, 92-99.

Gremaud, V., Goldscheider, N., 2010. Geometry and drainage of a retreating glacier overlying and recharging a karst aquifer, Tsanfleuron-Sanetsch, Swiss Alps. Acta Carsol. 39, 289-300.

Grunewald, K., Scheithauer, J., 2010. Europe's southernmost glaciers: response and adaptation to climate change. J. Glaciol. 42, 3-18.

Gusmeroli, A., Wolken, G.J., Arendt, A.A., 2014. Helicopter-borne radar imaging of snow cover on and around glaciers in Alaska. Ann. Glaciol. 55, 78-88.

Haeberli, W., Huggel, C., Paul, F., Zemp, M., 2013. Glacial responses to climate change. Treatise on Geomorphology 13, 152-175.

Hagg, W., Scotti, R., Villa, F., Mayer, E., Heilig, A., Mayer, C., Wennemar, T., Hock, T., 2017. Evolution of two cirque glaciers in Lombardy and their relation to climatic factors (1962-2016). Geogr. Ann. Ser. A Phys. Geogr. 99, 371-386.

Hamran, S.E., Gjessing, D.T., Hjelmstad, J., Aarholt, E., 1995. Ground penetrating synthetic pulse radar: dynamic range and modes of operation. J. Appl. Geophys. 33, 7-14.

Hausmann, H., Behm, M., 2010. Application of ground penetrating radar (GPR) in Alpine ice caves. Cryosphere Discuss. 4, 1365-1389.

Hélière, F., Lin, C.C., Corr, H., Vaughan, D., 2007. Radio echo sounding of Pine Island Glacier, West Antarctica: aperture synthesis processing and analysis of feasibility from space. IEEE Trans. Geosci. Remote Sens. 45 (8), 2573-2582.

Hughes, P.D., 2007. Recent behaviour of the debeli namet glacier, durmitor, Montenegro. Earth Surf. Process. Landforms 32, 1593-1602.

Hughes, P.D., 2009. Twenty-first century glaciers and climate in the Prokletije mountains, Albania. Arctic Antarct. Alpine Res. 41, 455-459.

Hughes, P.D., 2014. Little ice Age glaciers in the mediterraneanmountains. Méditerranée 122, 63-79.

Hughes, P.D., 2018. Little Ice Age glaciers and climate in the Mediterranean mountains: a new analysis. Cuadernos de investigación Geográphica/Geographycal Research Letters 44, 15-45. doi:10.18172/cig.3362.

Jol, H.M., 2009. Ground Penetrating Radar Theory and Application. first ed. Elsevier Science.

Kaser, G., Fountain, A.G., Jansson, P., 2003. A Manual for Monitoring the Mass Balance of Mountain Glaciers with Particular Attention to Low Latitude Characteristics. A contribution to the UNESCO HKH-Friend programme, Paris (France).

Kozamernik, E., Colucci, R.R., Stepišnik, U., Forte, E., Žebre, M., 2018. Spatial and climatic characterization of three glacial stages in the upper krnica valley, SE european Alps. Quat. Int. 470, 67-81.

Krellmann, Y., Triltzsch, G., 2012. Hera-g - a new helicopter GPR based on gated stepped frequency technology. In: $14^{\text {th }}$ International Conference on Ground Penetrating Radar (GPR). (Shanghai, China).

Looyenga, H., 1965. Dielectric constants of heterogeneous mixtures. Physica 31.

Machguth, H., Eisen, O., Paul, F., Hoelzle, M., 2006. Strong spatial variability of snow accumulation observed with helicopter-borne GPR on two adjacent alpine glaciers. Geophys. Res. Lett. 33, L13503.

Mattana, U., Varotto, M., 2010. Il ritiro del ghiacciaio della Marmolada nell'ultimo trentennio. Le Alpi Venete 1, 69-78. (in Italian).

Mercer, A., 2010. A DEM of the 2010 surface topography of Storglaciären, Sweden. J. Maps 12, 1112-1118.

Mercer, A., 2018. Studies in Glacier Mass Balance: Measurement and its Errors, Academic Dissertation for the Degree of Doctor of Philosophy in Physical Geography. University of Stockholm, Department of Physical Geography.

Merz, K., Green, A.G., Buchli, T., Springman, S.M., Maurer, H., 2015. A new 3D thin-skinned rock glacier model based on helicopter GPR results from the Swiss Alps. Geophys. Res. Lett. 42, 4464-4472.

Merz, K., Maurer, H.R., Buchli, T., Horstmeyer, H., Green, A.G., Springman, S.M., 2015 Evaluation of ground-based and helicopter ground-penetrating radar data acquired across an alpine rock glacier. Permafr. Periglac. Process, 26, 13-27. 
Navarro, F.J., Glazovsky, A.F., Macheret, Y., Vasilenko, E.V., Corcuera, M.I., Cuadrado, M.L., 2005. Ice- volume changes (1936-1990) and structure of Aldegondabreen, Spitsbergen. Ann. Glaciol. 42, 158-162.

Nistor, M.M., 2014. Using Landsat Images and Gis to assess the changes of Mer de Glace and Marmolada glaciers in the last three decades. Studia Ubb Geographia, Lix 1, 65-76.

Nojarov, P., Gachev, E., Grunewald, K., 2019. Recent behavior and possible future evolution of the glacieret in the cirque Golemiya Kazan in the Pirin Mountains under conditions of climate warming. J. Mt. Sci. 16, 16-29.

Oerlemans, J., 2005. Extracting a climate signal from 169 glacier records. Science 308, 675-677.

Pasta, M., Pavan, M., Sonda, D., Carollo, F., Cagnati, A., 2005. Prospezione di alcuni ghiacciai dolomitici tramite tecniche GPR e GPS. Neve e Valanghe 56, 50-59. (in Italian).

Paul, F., Barrand, N., Baumann, S., Berthier, E., Bolch, T., Casey, K., Frey, H., Joshi, S., Konovalov, V., Bris, R.L., Mölg, N., Nosenko, G., Nuth, C., Pope, A., Racoviteanu, A., Rastner, P., Raup, B., Scharrer, K., Steffen, S., Winsvold, S., 2013. On the accuracy of glacier outlines derived from remote-sensing data. Ann. Glaciol. 54, 171-182.

Pavan, M., Diolaiuti, G., Smiraglia, C., Maggi, V., D’Agata, C., 2000. Prospezioni sismiche e radar sul Ghiacciaio della Sforzellina, un nuovo approfondimento glaciologico nel gruppo Ortles-Cevedale. In: Lombardia, Neve e Valanghe, 41. pp. 6-13, (in Italian).

Plewes, L.A., Hubbard, B., 2001. A review of the use of radio echo sounding in glaciology. Prog. Phys. Geogr. 25 (2), 203-236.

RGI Consortium, 2017. Randolph Glacier Inventory - A Dataset of Global Glacier Outlines: Version 6.0: Technical Report, Global Land Ice Measurements from Space. (Colorado, USA).

Rutishauser, A., Maurer, H., Bauder, A., 2016. Helicopter-borne ground-penetrating radar investigations on temperate alpine glaciers: a comparison of different systems and their abilities for bedrock mapping. Geophysics 81, WA119-WA129.

Saintenoy, A., Friedt, J.M., Booth, A.D., Tolle, F., Bernard, E., Laffly, D., 2013. Deriving ice thickness, glacier volume and bedrock morphology of the Austre Love'nbreen (Svalbard) using ground penetrating radar. Near Surf. Geophys. 11, 253-261.

Scotti, R., Brardinoni, F., 2018. Evaluating millennial to contemporary time scales of glacier change in Val Viola, Central Italian Alps. Geogr. Ann. Ser. A Phys. Geogr. 1-21.

Scotti, R., Brardinoni, F., Crosta, G.B., 2014. Post-LIA glacier changes along a latitudinal transect in the Central Italian Alps. Cryosphere 8, 2235-2252.

Serrano, E., González-Trueba, J.J., Sabjosé, J.J., Del Río, L.M., 2011. Ice patch origin, evolution and dynamics in a temperate high mountain environment: the Jou Negro, Picos de Europa (NW Spain). Geogr. Ann. Ser. A Phys. Geogr. 93, 57-70.
Sharp, M., Gemmell, J.C., Tison, J.L., 1989. Structure and stability of the former subglacial drainage system of the glacier De Tsanfleuron, Switzerland. Earth Surf. Process. Landforms 14, 119-134.

Siegert, M.J., Hindmarsh, R., Corr, H., Smith, A.M., Woodward, J., King, E.C., Payne, T., Joughin, I., 2004. Subglacial lake ellsworth: a candidate for in situ exploration in west Antarctica. Geophys. Res. Lett. 31, L23403.

Smart, C.C., 1996. Statistical evaluation of glacier boreholes as indicators of basal drainage systems. Hydrol. Process. 10, 599-613.

Smiraglia, C., Diolaiuti, G., 2015. Il Nuovo catasto dei Ghiacciai italiano. Comitato Ev-K2-CNR Ed. Bergamo, p. 400. (in Italian).

Steenson, B.O., 1951. Radar Methods for the Exploration of Glaciers Unpublished Ph.D. thesis. Californian Institute of Technology, Pasedena, USA.

Dipartimento TerritorioAgricoltura, Ambiente e Foreste della Provincia Autonoma di TrentoRapporto ambientale del programma degli interventi di manutenzione e razionalizzazione degli impianti e delle strutture esistenti, legati alla pratica dello sci e degli interventi di valorizzazione ambientale e culturale, anche a fini turistici, relativo al ghiacciaio della Marmolada(in Italian)https://www.ladige.it/sites/ www.ladige.it/files/territory/attachment/2015/09/17/

Marmolada\%20I1\%20rapporto\%20ambientale.pdf201517 September 2015

Triglav Čekada, M., Zorn, M., Colucci, R.R., 2014. Area changes on Canin (Italy) and Triglav glaciers (Slovenia) from 1893 on based on archive imagery and Lidar. Geod. Vestn. 58 (2), 257-277. doi:10.15292/geodetski-vestnik.2014.02.274-313.

Wu, T., Li, S., Cheng, G., Nan, Z., 2005. Using ground-penetrating radar to detect permafrost degradation in the northern limit of permafrost on the Tibetan Plateau. Cold Reg. Sci. Technol. 41, 211-219.

Žebre, M., Stepišnik, U., 2015. Glaciokarst landforms and processes of the southern Dinaric Alps. Earth Surf. Process. Landforms 40, 1493-1505. doi:10.1002/esp.3731.

Zemp, M., Roer, I., Kääb, A., Hoelzle, M., Paul, F., Haeberli, W., 2008. Global Glacier Changes: Facts and Figures. World Glacier Monitoring Service.

Zemp, M., Jansson, P., Holmlund, P., Gartner-Roer, I., Koblet, T., Thee, P., Haeberli, W., 2010. Reanalysis of multi-temporal aerial images of Storglaciaren, Sweden (1959-99) - Part 2: comparison of glaciological and volumetric mass balances. Cryosphere 4, $345-357$.

Zemp, M., Thibert, E., Huss, M., Stumm, D., Rolstad Denby, C., Nuth, C., Nussbaumer, S.U., Moholdt, G., Mercer, A., Mayer, C., Joerg, P.C.,

Jansson, P., Hynek, B., Fischer, A., Escher-Vetter, H., Elvehøy, H., Andreassen, L.M., 2013. Reanalysing glacier mass balance measurement series. Cryosphere 7, 1227-1245.

Zhao, W., Forte, E., Colucci, R.R., Pipan, M., 2016. High-resolution glacier imaging and characterization by means of GPR attribute analysis. Geophys. J. Int. 206, 1366-1374. 